DOI: https://doi.org/10.24127/ajpm.v10i3.3980

\title{
PENGEMBANGAN INSTRUMEN KESIAPAN GURU MATEMATIKA PADA PEMBELAJARAN DARING DALAM PERSPEKTIF TPACK
}

\author{
Heru $^{1}$, Refi Elfira Yuliani ${ }^{2 *}$, Rieno Septra Nery $^{3}$, Nila Kesumawati ${ }^{4}$ \\ ${ }^{1,2 * 3}$ Universitas Muhammadiyah Palembang, Indonesia \\ ${ }^{4}$ Universitas PGRI Palembang, Indonesia \\ ${ }^{*}$ Corresponding author \\ Email: heroe.ump@gmail.com ${ }^{1)}$ \\ refielfirayuliani@gmail.com $^{2 *}$ \\ rienosn@gmail.com ${ }^{3}$ \\ nilakesumawati55@gmail.com ${ }^{4}$
}

Received 13 July 2021; Received in revised form 12 September 2021; Accepted 25 September 2021

\begin{abstract}
Abstrak
Implementasi pembelajaran daring menghadirkan konsekuensi logis bagi para guru untuk dapat mengintegrasikan kemampuan pedagogik (pedagogical knowledge), penguasaan konten/materi (content knowledge) dan penggunaan teknologi (technological knowledge) pada pembelajaran. Penelitian ini bertujuan mengembangkan Instrumen kesiapan guru matematika dalam melaksanakan pembelajaran daring dalam perspektif Technological Pedagogical and Content Knowledge (TPACK). Peneliatian ini, merupakan penelitian pengembangan (development research). Pengembangan instrumen TPACK pembelajaran daring menggunakan prosedur pengembangan yang terdiri dari beberapa langkah antara lain: 1) perumusan latar belakang (background); 2) konseptualisasi (questionnaire conceptualization); 3) format dan analisis data (Format and Data Analysis); 4) penentuan validitas (Establishing Validity), dan; 5) penentuan reliabilitas (Establishing Reliability). Subjek penelitian adalah guru yang mengajar muatan pelajaran Matematika SD kelas atas (kelas 4,5, dan 6), guru mata pelajaran Matematika SMP sederajat dan SMA sederajat sebanyak 40 orang guru. Berdasarkan hasil validasi konstruk dan Bahasa yang dilakukan oleh expert review menunjukkan bahwa instrumen telah valid dan siap untuk di uji validasi lapangan. Hasil uji validasi lapangan yang dianalisis menggunakan Rasch model diperoleh satu pernyataan pada komponen Technology Knowledge (TK) yang tidak valid, sementara 44 pernyataan laiinya dinyatakan valid. Hasil uji reliabilitas menunjukkan bahwa instrumen kuiseoner reliabel. Berdasarkan hasil analisis validitas dan reliabilitas menggunakan Rasch model, hanya 44 pernyataan yang dapat digunakan. Hasil penelitian ini menunjukkan bahwa 44 pernyataan instrumen yang telah dikembangkan layak digunakan untuk mengukur kesiapan guru matematika pada pembelajaran daring dalam perspektif TPACK.
\end{abstract}

Kata kunci: Kesiapan Guru, Matematika, TPACK

\begin{abstract}
The implementation of online learning presents logistical consequences for teachers to be able to integrate pedagogic abilities (pedagogical knowledge), mastery of content/materials (content knowledge) and the use of technology (technology knowledge) in learning. This study aims to develop a mathematics teacher readiness instrument in carrying out bold learning in the perspective of Technological Pedagogical and Content Knowledge (TPACK). This research is development research. The instrument for developing TPACK for bold learning uses a development procedure consisting of several steps, including 1) the formulation of the background; 2) conceptualization (questionnaire conceptualization); 3) format and data analysis (Format and Data Analysis); 4) the existence of validity (Establishing Validity), and; 5) certainty (Establishing Reliability). The research subjects were teachers who taught mathematics for upper grades of elementary school (grades 4,5, and 6), 40 junior high school mathematics teachers, and the equivalent of 40 teachers. The construct and language validation conducted by expert review shows that the instrument is valid and ready to be tested for field validation. The field test results, which were analyzed using the Rasch model, obtained one statement on the Knowledge Technology (TK) component that was invalid; 44 statements were declared valid. The results of the reliability test showed that the questionnaire instrument was reliable. Results Based on the validity and reliability analysis using the Rasch model, only 44 statements can be used. The results of this study indicate that the 44 statements that have been developed are appropriate to measure the readiness of mathematics teachers in bold learning in the TPACK perspective.
\end{abstract}

Keywords: Teacher Readiness, Mathematics, TPACK

This is an open access article under the Creative Commons Attribution 4.0 International License 
DOI: https://doi.org/10.24127/ajpm.v10i3.3980

\section{PENDAHULUAN}

Eksponensial digitalisasi di era Pandemi Corona Virus Disease (Covid19) memberikan dampak yang sangat signifikan terhadap dunia pendidikan dan pembelajaran, khususnya di Indonesia. Sejak diumumkannya Surat Edaran Menteri Pendidikan dan Kebudayaan Republik Indonesia (Kemdikbud, 2020a, 2020b), yang menyatakan bahwa seluruh peserta didik dari tingkat SD sampai dengan Perguruan Tinggi melaksanakan pembelajaran daring.

Sementara itu, problematika yang dihadapi oleh guru dan siswa dalam melaksanakan pembelajaran daring begitu kompleks, diantaranya adalah: 1) akses internet yang tidak merata; 2) kesenjangan kualifikasi guru; 3) kualitas pendidikan; dan, 4) kurangnya keterampilan ICT (Azzahra, 2020). Samnufida dkk (2021) menemukan salah satu kesulitan guru pada pembelajaran matematika yang dilakukan secara daring dalam membantu perkembangan komunikasi matematis siswa adalah belum menguasai teknis pembelajaran daring. Hal ini senada dengan penelitian tentang kesiapan guru fisika dan matematika dalam melaksanakan pembelajaran daring oleh Fajriana dan Safriana (2021) menunjukkan bahwa guru siap melakukan pembelajaran daring, namun perlu meningkatkan kemampuan pengintegrasian teknologi dalam pembelajaran.

Di sisi yang lain, pada era digital saat ini terdapat teknologi yang ketersediannya terus meningkat, yakni perangkat mobile/smartphone (Pratama, Lestari, \& Astutik, 2020). Studi meta analisis terhadap 80 penelitian yang dilakukan oleh Chen et. All. (2020) menunjukkan bahwa pembelajaran bahasa melalui perangkat selular lebih efektif daripada menggunakan pendekatan pembelajaran konvensional. Selain itu, terdapat peningkatan signifikan terhadap penggunaan internet masyarakat Indonesia sejak tahun 2015 sampai dengan tahun 2020 yang dapat dilihat pada Gambar 1. Peningkatan penggunaan smartphone dan jaringan internet telah mengubah paradigma pembelajaran yang bergeser dari pembelajaran tatap muka menuju pada online learning (pembelajaran daring).

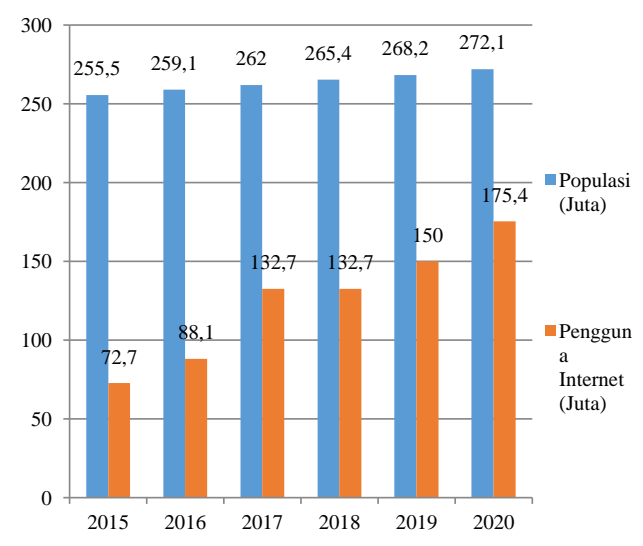

Gambar 1. Statistik populasi dan pengguna internet masyarakat Indonesia tahun 2015 - 2020

(Kemp, 2020)

Implementasi pembelajaran daring menghadirkan konsekuensi logis bagi para guru yaitu dalam mengintegrasikan kemampuan pedagogik (pedagogical knowledge), penguasaan konten/materi (content knowledge) dan penggunaan teknologi (technological knowledge) pada pembelajaran.

Technological, Pedagogical, and Content Knowledge (TPACK) adalah kerangka kerja yang memperkenalkan hubungan dan kompleksitas antara ketiga komponen dasar pengetahuan, yaitu pengetahuan teknologi, pedagogik, dan konten/materi ajar (Mishra \& Koehler, 2006; Schmidt et al., 2009). Irisan ketiga tipe pengetahuan tersebut dapat dilihat pada Gambar 2. 


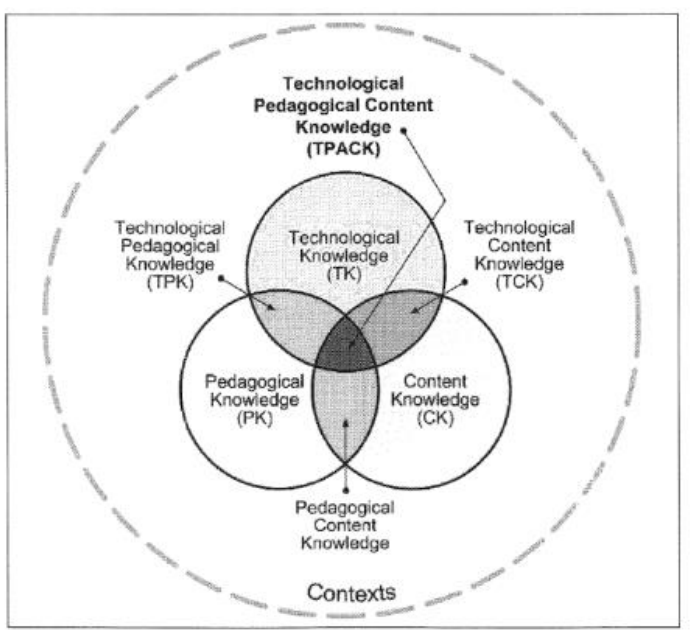

Gambar 2. Kerangka technological pedagogical and content knowledge

(Schmidt et al., 2009)

Kerangka TPACK yang telah dikembangkan, mengalami banyak pengembangan diantaranya yang dilakukan Valtonen (2017) yang memperkenalkan kuesioner TPACK baru, kuesioner TPACK-21 yang didasarkan pada keterampilan abad kedua puluh satu. Misieng (2018) mengadaptasi instrumen TPACK Schmidt et al., (2009) dan melakukan validasi untuk mengukur kesiapan guru bahasa dalam menggunakan teknologi. Kiray (2016) mengembangkan instrumen Skala Seflf-efficacy TPACK untuk mahasiswa calon guru. Selain itu kerangka TPACK juga digunakan oleh peneliti sebagai instrumen penelitian, seperti yang dilakukan Yuliani dan Heru (2021)

Pelaksanaan pembelajaran daring yang menjadi kebijakan pemerintah dalam membatasi aktivitas sosial disebabkan wabah covid-19 telah memberikan warna baru dalam dunia pendidikan. Problematika dalam melaksanakan pembelajaran daring selalu memperhatikan pada aspek kesipaan infrastruktur, sarana dan prasarana seperti jaringan, perangkat untuk melaksanakan pembelajaran daring seperti smartphone dan komputer (CPU)/laptop. Kesiapan dari sisi tenaga pendidik (guru) juga perlu perlu diukur, dalam rangka mengoptimalkan aktivitas pembelajaran daring yang akan berlangsung di era New Normal.

Kesiapan dalam melaksanakan pembelajaran daring tentunya tidak terlepas dari kerangka TPACK yang mengintegrasikan kemampuan/ keterampilan pedagogik, penguasaan materi ajar dan penggunaan teknologi dalam pembelajaran. Penelitian ini bertujuan untuk mengembangkan instrumen kesiapan guru matematika dalam melaksankan pembelajaran daring berdasarkan perspektif TPACK yang didaptasi dari kerangka TPACK Schmidt et al., (2009) dan kuesioner TPACK-21 (Valtonen et al., 2017) untuk mengukur kesiapan guru

\section{METODE PENELITIAN}

Jenis penelitian ini adalah penelitian pengembangan (Development Research). Penelitian ini bertujuan untuk menghasilkan instrumen kesiapan guru pada pembelajaran daring dalam perspektif TPACK. Subjek penelitian adalah guru Matematika SD, SMP dan SMA Sumatera Selatan yang berjumlah 40 orang guru.

Pengembangan instrumen menggunakan prosedur pengembangan yang model Radhakrishna yang terdiri dari beberapa langkah antara lain: 1) perumusan latar belakang (background); 2) konseptualisasi (questionnaire conceptualization); 3) format dan analisis data (format and data analysis); 4) penentuan validitas (establishing validity), dan; 5) penentuan reliabilitas (establishing reliability). Prosedur pengembangan dapat dilihat pada Gambar 3. 
DOI: https://doi.org/10.24127/ajpm.v10i3.3980

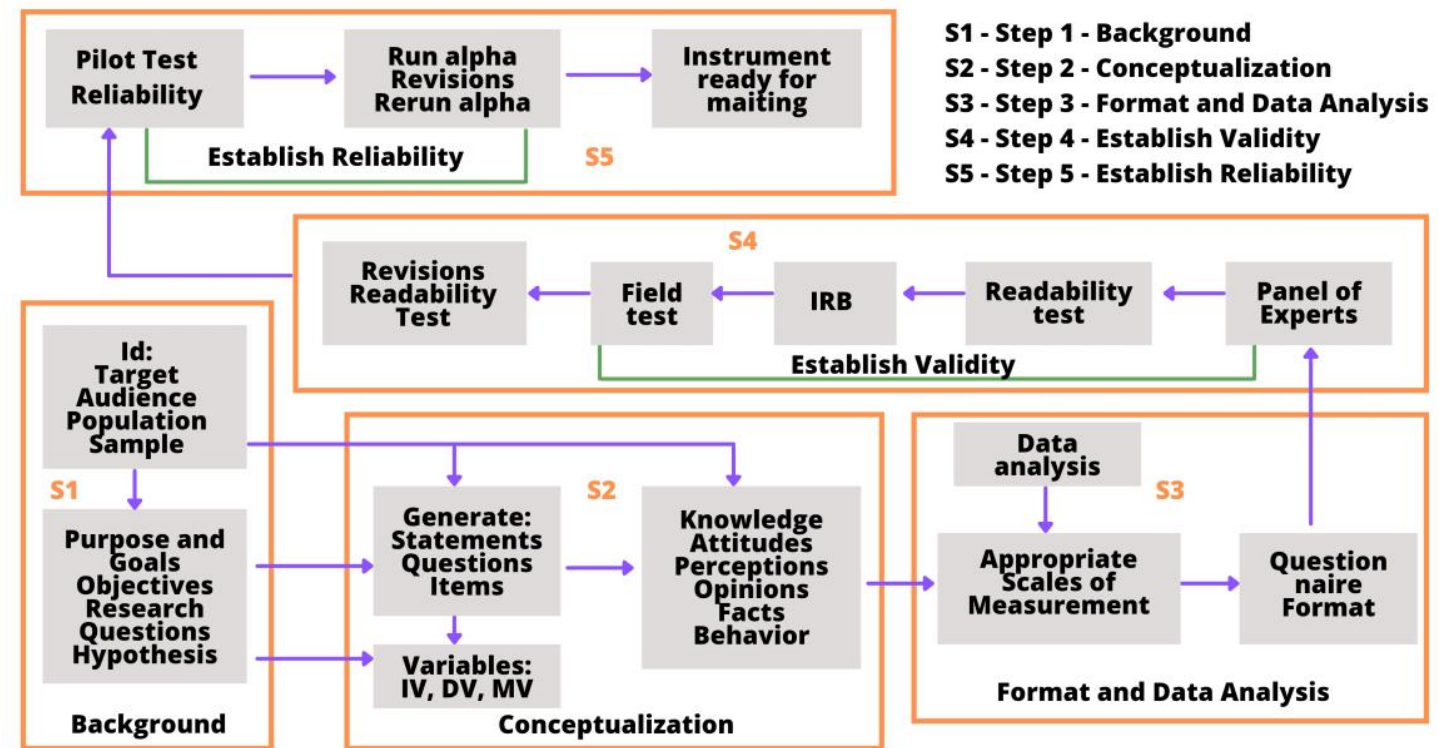

Gambar 3. Urutan pengembangan instrumen kuiseoner (Radhakrishna, 2007)

Instrumen yang digunakan pada penelitian ini adalah penilaian kuesioner yang digunakan oleh expert review untuk menilai kevalidan instrumen kuesioner yang dikembangkan serta kuesioner itu sendiri. Expert review yang melakukan penilaian terhadap instrumen yang dikembangkan terdiri dari tiga orang pakar dari bidang Pendidikan Matematika dan 1 orang pakar di bidang Pendidikan Bahasa Indonesia. Analisis data validasi oleh expert review dilakukan secara kualitatif. Hasil kuesioner yang telah di review oleh expert review diperbaiki sesuai dengan saran yang kemudian dinilai kembali oleh expert review dan dilihat kesesuaian perbaikan yang harus diperbaiki dengan saran expert review. Setelah instrumen dinyatakan valid oleh expert review, selanjutnya dilakukan ujicoba instrumen untuk melihat validitas dan reliabiitas.

Uji lapangan yang dilakukan untuk melihat validitas dan reliabilitas menggunakan perangkat lunak (software) analisis Rasch Model yaitu aplikasi Winsteps. Dalam menentukan validitas menggunakan model Rasch, kriteria yang digunakan untuk memeriksa kesesuaian butir soal yang tidak sesuai (outliers atau misfis) teridiri dari tiga kriteria, antara lain:

1. Outfit Mean Square (MNSQ) yang diterima: $0,5<\mathrm{MNSQ}<1,5$

2. Nilai Outfit Z-Standard (ZSTD) yang diterima: $-0,2<$ ZSTD $<2,0$

3. Nilai Point Measure Correlation (PT Mean Corr): 0,4 < PT Measure Corr $<0,85$.

Nomor pernyataan yang dinyatakan valid minimal harus memenuhi 2 dari 3 kriteria yang telah ditentukan (Sumintono \& Widhiarso, 2015)

\section{HASIL DAN PEMBAHASAN}

\section{Perumusan latar belakang (background)}

Latar belakang dari penelitian ini berdasarkan kebutuhan terhadap instrumen yang dapat mengukur kesiapan guru matematika dalam melakukan pembelajaran daring. Penelitian ini bertujuan untuk mengembangkan instrumen kesiapan guru matematika pada pembelajaran daring berdasarkan perspektif TPACK 
DOI: https://doi.org/10.24127/ajpm.v10i3.3980

yang valid. Subjek penelitian yang menjadi responden adalah Guru Matematika SD, SMP dan SMA sederajat sebanyak 40 orang responden.

\section{Konseptualisasi (questionnaire conceptualization)}

Instrumen TPACK yang dikembangkan adalah modifikasi instrumen yang telah dikembangkan oleh (Schmidt et al., 2009) dan kuesioner TPACK-21 (Valtonen et al., 2017). Komponen dan pernyataan instrumen kesiapan guru matematika pada pembelajaran daring berdasarkan perspektif TPACK yang dikembangkan dapat dilihat pada Tabel 1.

Tabel 1. Komponen dan pernyataan instrumen kesiapan guru matematika pada pembelajaran daring berdasarkan perspektif TPACK

\begin{tabular}{|c|c|c|}
\hline Komponen & Pernyataan & Butir \\
\hline \multirow[t]{6}{*}{$\begin{array}{l}\text { Technology Knowledge } \\
\text { (TK) }\end{array}$} & $\begin{array}{l}\text { Saya tahu bagaimana menyelesaikan masalah teknis saya } \\
\text { sendiri terkait penggunaan teknologi }\end{array}$ & 1 \\
\hline & Saya bisa belajar teknologi dengan mudah & 2 \\
\hline & Saya akrab dengan Teknologi baru dan fitur-fiturnya & 3 \\
\hline & $\begin{array}{l}\text { Saya memiliki keterampilan teknis yang saya butuhkan } \\
\text { untuk menggunakan teknologi. }\end{array}$ & 4 \\
\hline & $\begin{array}{l}\text { Saya mengetahui beberapa situs wab yang menyediakan } \\
\text { fasilitas pembelajaran daring }\end{array}$ & 5 \\
\hline & $\begin{array}{l}\text { Saya mengetahui berbagai aplikasi/software yang dapat } \\
\text { digunakan untuk pembelajaran daring. }\end{array}$ & 6 \\
\hline \multirow[t]{5}{*}{$\begin{array}{l}\text { Content } \\
\text { (CK) }\end{array}$} & $\begin{array}{l}\text { Saya memiliki pengetahuan yang cukup dalam tentang } \\
\text { materi matematika sekolah }\end{array}$ & 7 \\
\hline & Saya bisa menggunakan cara berpikir matematis & 8 \\
\hline & $\begin{array}{l}\text { Saya memiliki pengatuhan yang baik terkait kurikulum } \\
\text { matematika sekolah }\end{array}$ & 9 \\
\hline & $\begin{array}{l}\text { Saya memiliki berbagai cara dan strategi untuk } \\
\text { mengembangkan pemahaman matematika. }\end{array}$ & 10 \\
\hline & $\begin{array}{l}\text { Saya mengikuti perkembangan informasi terbaru terkait } \\
\text { matematika sekolah }\end{array}$ & 11 \\
\hline \multirow{11}{*}{$\begin{array}{l}\text { Pedagogic } \\
(\mathrm{PK})\end{array}$} & Saya dapat membuat RPP untuk pembelajaran daring & 12 \\
\hline & $\begin{array}{l}\text { Saya dapat menggunakan berbagai pendekatan pengajaran } \\
\text { di kelas daring }\end{array}$ & 13 \\
\hline & $\begin{array}{l}\text { Saya dapat menyesuaikan gaya mengajar saya dengan } \\
\text { peserta didik pada kelas daring }\end{array}$ & 14 \\
\hline & $\begin{array}{l}\text { Saya tahu bagaimana cara menilai proses belajar peserta } \\
\text { didik pada kelas daring }\end{array}$ & 15 \\
\hline & $\begin{array}{l}\text { Saya tahu bagaimana cara menilai hasil belajar peserta } \\
\text { didik dalam berbagai cara. }\end{array}$ & 16 \\
\hline & $\begin{array}{l}\text { Saya mengetahui miskonsepsi yang sering dialami oleh } \\
\text { siswa }\end{array}$ & 17 \\
\hline & $\begin{array}{l}\text { Saya tahu bagaimana mengatur dan mengelola kelas } \\
\text { daring }\end{array}$ & 18 \\
\hline & Saya mendukung pemikiran kritis siswa & 19 \\
\hline & Saya mendukung pemikiran reflektif siswa & 20 \\
\hline & Mendukung keterampilan pemecahan masalah siswa & 21 \\
\hline & Mendukung pemikiran kreatif siswa & 22 \\
\hline
\end{tabular}


DOI: https://doi.org/10.24127/ajpm.v10i3.3980

\begin{tabular}{|c|c|c|}
\hline Komponen & Pernyataan & Butir \\
\hline \multirow[t]{6}{*}{$\begin{array}{l}\text { Pedagogical Content } \\
\text { Knowledge (PCK) }\end{array}$} & $\begin{array}{l}\text { Saya tahu bagaimana memilih pendekatan pengajaran } \\
\text { yang efektif untuk membimbing siswa berpikir dan } \\
\text { belajar dalam matematika. }\end{array}$ & 23 \\
\hline & Saya dapat mengatur dan mengelola kelas daring & 24 \\
\hline & $\begin{array}{l}\text { Dalam pembelajaran matematika, Saya mendukung } \\
\text { pemikiran kritis siswa }\end{array}$ & 25 \\
\hline & $\begin{array}{l}\text { Dalam pembelajaran matematika, Saya mendukung } \\
\text { keterampilan pemecahan masalah siswa }\end{array}$ & 26 \\
\hline & $\begin{array}{l}\text { Dalam pembelajaran matematika, Saya mendukung } \\
\text { pemikiran kreatif siswa }\end{array}$ & 27 \\
\hline & $\begin{array}{l}\text { Dalam pembelajaran matematika, Saya mendukung } \\
\text { pemikiran reflektif siswa }\end{array}$ & 28 \\
\hline \multirow[t]{3}{*}{$\begin{array}{l}\text { Technology Content } \\
\text { Knowledge (TCK) }\end{array}$} & $\begin{array}{l}\text { Saya mengetahui beberapa situs wab yang menyediakan } \\
\text { informasi pendukung untuk siswa terkait materi } \\
\text { matematika yang dipelajari saat pembelajaran daring. }\end{array}$ & 29 \\
\hline & $\begin{array}{l}\text { Saya tahu media pembelajaran matematika berbasis TIK } \\
\text { lainnya untuk mempermudah siswa memahami materi. }\end{array}$ & 30 \\
\hline & $\begin{array}{l}\text { Saya tahu aplikasi/software yang dapat digunakan siswa } \\
\text { untuk menunjang siswa agar dapat memahami } \\
\text { matematika. }\end{array}$ & 31 \\
\hline \multirow[t]{3}{*}{$\begin{array}{l}\text { Technology Pedagogical } \\
\text { Knowledge (TPK) }\end{array}$} & $\begin{array}{l}\text { Saya dapat mengguankan beberapa situs web yang } \\
\text { menyediakan fitur pembelajran daring untuk kelas saya. }\end{array}$ & 32 \\
\hline & $\begin{array}{l}\text { Saya dapat mengguankan beberapa aplikasi/software yang } \\
\text { menyediakan fitur pembelajran online untuk kelas saya. }\end{array}$ & 33 \\
\hline & $\begin{array}{l}\text { Pada pembelajaran daring, Saya menggunakan media } \\
\text { pembelajaran berbasis TIK lainnya untuk menunjang } \\
\text { proses pembelajaran }\end{array}$ & 34 \\
\hline \multirow[t]{7}{*}{$\begin{array}{l}\text { Technology Pedagogical } \\
\text { and Content Knowledge } \\
(\text { TPACK) }\end{array}$} & $\begin{array}{l}\text { Saya dapat mengelola pembelajaran daring mata pelajaran } \\
\text { matematika dengan memanfaatkan situs web yang } \\
\text { memiliki fitur pembelajaran daring sesuai dengan } \\
\text { pendekatan pembelajaran yang saya pilih. }\end{array}$ & 35 \\
\hline & $\begin{array}{l}\text { Saya dapat mengelola pembelajaran daring mata pelajaran } \\
\text { matematika menggunakan aplikasi/ software } \\
\text { pembelajaran daring pendekatan pembelajaran yang saya } \\
\text { pilih }\end{array}$ & 36 \\
\hline & $\begin{array}{l}\text { Saya dapat menyampaikan materi pembelajaran } \\
\text { matematika pada kelas daring saya. }\end{array}$ & 37 \\
\hline & $\begin{array}{l}\text { Saya memanfaatkan beberapa situs wab yang } \\
\text { menyediakan informasi pendukung untuk siswa terkait } \\
\text { materi matematika yang dipelajari saat pembelajaran } \\
\text { daring. }\end{array}$ & 38 \\
\hline & $\begin{array}{l}\text { Saya memanfaatkan media pembelajaran matematika } \\
\text { berbasis TIK lainnya untuk mempermudah siswa } \\
\text { memahami materi. }\end{array}$ & 39 \\
\hline & $\begin{array}{l}\text { Saya tahu bagaimana mengembangkan kemampuan } \\
\text { berpikir matematis siswa melalui pembelajaran daring } \\
\text { dengan meemanfaatkan TIK (Website, aplikasi, media } \\
\text { pembelajaran berbasis TIK lainnya) }\end{array}$ & 40 \\
\hline & $\begin{array}{l}\text { Saya tahu bagaimana mengembangkan kemampuan } \\
\text { berpikir kritis siswa melalui pembelajaran daring dengan }\end{array}$ & 41 \\
\hline
\end{tabular}


DOI: https://doi.org/10.24127/ajpm.v10i3.3980

\begin{tabular}{|c|c|c|}
\hline Komponen & Pernyataan & Butir \\
\hline & $\begin{array}{l}\text { meemanfaatkan TIK (Website, aplikasi, media } \\
\text { pembelajaran berbasis TIK lainnya) }\end{array}$ & \\
\hline & $\begin{array}{l}\text { Saya tahu bagaimana mengembangkan kemampuan } \\
\text { berpikir kreatif siswa melalui pembelajaran daring dengan } \\
\text { meemanfaatkan TIK (Website, aplikasi, media } \\
\text { pembelajaran berbasis TIK lainnya) }\end{array}$ & 42 \\
\hline & $\begin{array}{l}\text { Saya tahu bagaimana mengembangkan kemampuan } \\
\text { berpikir reflektif siswa melalui pembelajaran daring } \\
\text { dengan meemanfaatkan TIK (Website, aplikasi, media } \\
\text { pembelajaran berbasis TIK lainnya) }\end{array}$ & 43 \\
\hline & $\begin{array}{l}\text { Saya tahu bagaimana mengembangkan kemampuan } \\
\text { penyelesaian masalah siswa melalui pembelajaran daring } \\
\text { dengan meemanfaatkan TIK (Website, aplikasi, media } \\
\text { pembelajaran berbasis TIK lainnya) }\end{array}$ & 44 \\
\hline & $\begin{array}{l}\text { Saya dapat membantu teman sejawat dalam melakukan } \\
\text { pembelajaran daring dengan memadukan konten/materi, } \\
\text { pendekatan pembelajaram dan teknologi. }\end{array}$ & 45 \\
\hline
\end{tabular}

\section{Format dan analisis data (Format} and Data Analysis)

Pada tahap ini peneliti menentukan format kuiseoner diantaranya: penulisan pernyataan, pemilihan skala pengukuran yang sesuai, tata letak kuesioner, format, urutan pertanyaan, ukuran huruf (font), sampul depan dan belakang, dan analisis data yang diusulkan. Skala yang digunakan pada instrumen yang dikembangkan adalah skala likert

Instrumen yang akan digunakan pada saat uji validasi oleh expert review adalah kuisioner dalam bentuk lembaran (printout). Setelah instrumen diperbaiki berdasarkan saran pakar, instrumen selanjutnya disajikan secara online (daring) menggunkaan aplikasi google form yang merupakan bagian dari fasilitas/layanan dari Google yang diberikan pada pengguna untuk membuat survei, form pendaftaran ataupun soal secara online

Format kuesioner yang digunakan menggunakan google form. Adapun bentuk dari kuesioner dalam bentuk google form dapat dilihat pada Gambar 4.

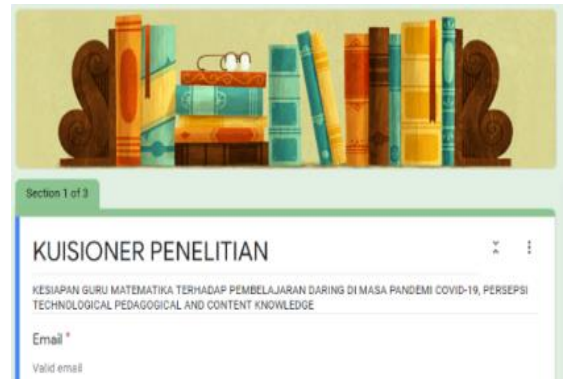

Gambar 4. Tampilan kuiseoner yang dibagikan melalui google form

Kuisioner pada penelitian ini disusun untuk memperoleh persetujuan guru/responden dengan menggunakan skala likert 1 - 5 dengan kategori:1 (Sangat tidak setuju); 2 (Tidak Setuju); 3 (Netral), 4 (Setuju); 5 (Sangat Setuju). Contoh isi google form dapat dilihat pada Gambar 5.

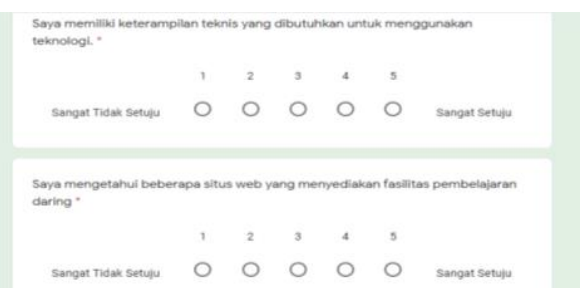

Gambar 5. Tampilan pernyataan dan pilihan yang terdapat pada kuesioner pada google form 
DOI: https://doi.org/10.24127/ajpm.v10i3.3980

\section{Penentuan validitas (Establishing Validity)}

Penentuan validitas diperoleh dengan melakukan expert review dan uji lapangan. Pada penelitian ini, dilakukan uji validitas oleh expert review yang terdiri dari 3 orang pakar bidang Pendidikan Matematika yang melakukan validasi konstruk dan 1 orang pakar bidang Bahasa yang melakukan validasi tata bahasa yang digunakan dalam instrumen kuiseoner.

Pada validasi konstruk, expert review melakukan review per item pernyataan yang disesuaikan dengan kisi-kisi instrumen serta memberikan komentar/saran bahkan memberikan saran perbaikan terhadap redaksi pernyataan. Berdasarkan saran expert review, kemudian dilakukan perbaikan. Hasil perbaikan tersebut disampaikan kembali pada expert review untuk diamati kesesuaian instrumen yang diperbaiki dengan saran yang telah diberikan oleh expert review.

Contoh saran yang diberikan expert review pada pernyataan nomor 10. Pernyataan sebelumnya adalah "Saya memiliki berbagai cara dan strategi untuk mengembangkan pemahaman matematika”. Perbaikan yang dilkukan berdasarkan saran expert review adalah "Saya memiliki pengetahuan untuk mengembangkan pemahaman matematika".

Setelah instrumen dinyatakan layak untuk digunakan oleh expert review, langkah selanjutnya adalah melakukan uji lapangan untuk melihat validitas dan reliabilitas isntrumen yang dikembangkan. Contoh penilaian validasi konstruk oleh expert review dalam bidang Pendidikan Matematika dapat dilihat pada Gambar 6.

\begin{tabular}{|c|c|c|c|c|c|c|}
\hline 9 & $\begin{array}{l}\text { Saya memiliki pengetahuan yang baik terkait } \\
\text { kurikulum matematika sekolah }\end{array}$ & & & $\checkmark$ & & Sesuai \\
\hline 10 & $\begin{array}{l}\text { Saya memiliki berbagai cara dan strategi untuk } \\
\text { mengembangkan pemahaman matematika. }\end{array}$ & & 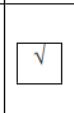 & & & $\begin{array}{l}\text { Masuk pedagogiknya, seharusnya pernyataannya } \\
\text { Saya memiliki pengetahuan untuk mengembangkan } \\
\text { pemahaman matematika }\end{array}$ \\
\hline 11 & $\begin{array}{l}\text { Saya mengikuti perkembangan informasi terbaru } \\
\text { terkait matematika sekolah }\end{array}$ & & & $\checkmark$ & & Sesuai \\
\hline 12 & $\begin{array}{l}\text { Saya dapat membuat RPP untuk pembelajaran } \\
\text { daring }\end{array}$ & & L & $\sqrt{ }$ & & Sesuai \\
\hline 13 & $\begin{array}{l}\text { Saya dapat menggunakan berbagai pendekatan } \\
\text { pengajaran di kelas daring }\end{array}$ & & $L$ & V & & Sesuai \\
\hline
\end{tabular}

Gambar 6. Contoh penilaian validasi konstruk oleh expert review

Uji validasi selanjutnya adalah validasi bahasa. Pada validasi bahasa, expert review melakukan review per item pernyataan yang ditinjau dari kejelasan bahasa atau redaksional dari setiap butir pernyataan berdasarkan ketentuan baku yang telah ditetapkan. Saran perbaikan yang diberikan oleh expert review kemudian diperbaiki dan selanjutnya disampaikan kembali kepada expert review untuk dilihat kesesuaian perbaikan degan saran yang diberikan sebelumnya. Beberapa contoh dari penilaian yang diberikan oleh expert review yang dalam hal ini adalah pakar Pendidikan Bahasa Indonesia dapat dilihat pada Gambar 7. 
DOI: https://doi.org/10.24127/ajpm.v10i3.3980

\begin{tabular}{|c|c|c|c|c|}
\hline \multirow{2}{*}{ No. } & \multirow{2}{*}{ Pernyataan } & \multicolumn{2}{|c|}{ Penialain } & \multirow{2}{*}{ Komentar/Saran Perbaikan } \\
\hline & & Valid & Tidak & \\
\hline 6 & $\begin{array}{l}\text { Saya mengetahui berbagai aplikasi/software yang } \\
\text { dapat digunakan untuk pembelajaran daring. }\end{array}$ & & \begin{tabular}{|l} 
\\
\end{tabular} & Kata sofware dan kata daring dicetak miring \\
\hline 7 & $\begin{array}{l}\text { Saya memiliki pengetahuan materi matematika } \\
\text { sekolah yang memadai }\end{array}$ & & $\sqrt{ }$ & Kata tentang dibuang saja \\
\hline 8 & Saya dapat menggunakan cara berpikir matematis & & $\sqrt{ }$ & Sebaiknya kata bisa diganti dengan kata dapat \\
\hline 9 & $\begin{array}{l}\text { Saya memiliki pengatuhan yang memadai terkait } \\
\text { kurikulum matematika sekolah }\end{array}$ & & $\sqrt{ }$ & Sebaiknya kata baik diganti dengan kata memadai atau cukup \\
\hline 10 & $\begin{array}{l}\text { Saya memiliki berbagai cara dan strategi untuk } \\
\text { mengembangkan pemahaman matematika. }\end{array}$ & & $\sqrt{ }$ & Tidak ada perbaikan \\
\hline 11 & $\begin{array}{l}\text { Saya mengikuti perkembangan informasi terbaru } \\
\text { terkait matematika sekolah }\end{array}$ & & $\sqrt{ }$ & Tidak ada perbaikan \\
\hline
\end{tabular}

Gambar 7. Contoh penilaian kuisioner oleh pakar Bahasa

Instrumen yang telah layak berdasarkan hasil penilaian oleh expert review dilakukan uji lapangan, untuk melihat validitas instrumen kuiseoner yang dikembangkan. Uji lapangan dilakukan terhadap 40 guru yang mengajar muatan matematika pada jenjang SD kelas atas (4,5 dan 6) guru matematika SMP dan SMA sederajat. Analisis hasil dilakukan dengan menggunakan instrumen Rasch Model (Sumintono \& Widhiarso, 2013, 2015). Hasil uji validitas lapangan Instrumen TPACK Pembelajaran Daring menggunakan Rasch Model dapat dilihat pada Gambar 8.

\begin{tabular}{|c|c|c|c|c|c|c|c|c|c|c|c|c|c|c|}
\hline $\begin{array}{l}\text { | ENTRY } \\
\text { | NUMBER }\end{array}$ & $\begin{array}{l}\text { TOTAL } \\
\text { SCORE }\end{array}$ & $\begin{array}{l}\text { TOTAL } \\
\text { COUNT }\end{array}$ & MEASURE & $\begin{array}{l}\text { MODEL } \\
\text { S.E. }\end{array}$ & I & $\underset{\text { ZSTD }}{\text { ZIT }}$ & I ou & FIT I & PT & T-ME & $\begin{array}{l}\text { SURE I } \\
\text { EXP. }\end{array}$ & $\begin{array}{r}\text { EXACT } \\
\text { OBS\% }\end{array}$ & $\begin{array}{l}\text { MATCH } \\
\text { EXP\% }\end{array}$ & Item \\
\hline 1 & 149 & 40 & .07 & $.27 \mid$ & 1.76 & 2.81 & 11.62 & $2.3 \mid$ & |A & .44 & $.68 \mid$ & 52.5 & 60.9 & TK1 \\
\hline 4 & 146 & 40 & .28 & .261 & 11.36 & 1.51 & 11.47 & 1.91 & 18 & .44 & .681 & 65.0 & 61.01 & $7 \mathrm{TR4}$ \\
\hline 45 & 147 & 40 & .21 & .27 & 1.35 & $1.5 \mid$ & 1.31 & $1.3 \mid$ & ic & .74 & .68 & 62.5 & 61.1 & TPACK 11 \\
\hline 38 & 145 & 40 & .35 & $.26 \mid$ & 1.35 & $1.5 \mid$ & 1.29 & $1.2 \mid$ & ID & .67 & .68 & 70.0 & 60.8 & TPACK 4 \\
\hline 12 & 147 & 40 & .21 & .27 & 1.28 & $1.2 \mid$ & 11.31 & $1.3 \mid$ & IE & .43 & .68 & 57.5 & 61.1 & PK1 \\
\hline 2 & 156 & 40 & -.44 & .27 & 1.30 & $1.3 \mid$ & 1.26 & $1.1 \mid$ & F & .42 & .671 & 57.5 & 60.1 & TK2 \\
\hline 37 & 149 & 40 & .07 & .27 & 1.24 & 1.0 & 1.18 & .81 & IG & .65 & $.68 \mid$ & 70.0 & 60.9 & TPACK 3 \\
\hline 41 & 134 & 40 & 1.09 & $.26 \mid$ & 1.21 & .9 & 1.20 & .91 & |н & .67 & $.69 \mid$ & 60.0 & 59.2 & TPACK 7 \\
\hline 25 & 163 & 40 & -.98 & .28 & 1.20 & .9 & 1.11 & .51 & II & .65 & .65 & 60.0 & 61.2 & PCK 3 \\
\hline 34 & 146 & 40 & .28 & $.26 \mid$ & 1.19 & .8 & 1.16 & .71 & [j & .76 & .68 & 60.0 & 61.0 & TPK3 \\
\hline 43 & 135 & 40 & 1.02 & $.26 \mid$ & 1.17 & .8 & 1.16 & .71 & $\mathrm{k}$ & .66 & $.69 \mid$ & 70.0 & 59.5 & TPACK9 \\
\hline 6 & 150 & 40 & .00 & .27 & 1.16 & .71 & 1.12 & $.6 \mid$ & $\mathrm{L}$ & .67 & .68 & 60.0 & 60.7 & TK6 \\
\hline 28 & 162 & 40 & -.90 & .28 & 1.13 & .71 & 11.07 & .31 & Im & .65 & .65 & 67.5 & 60.9 & PCK6 \\
\hline 3 & 145 & a & 35 & 261 & 1113 & أ & 1112 & 6i & InL & 55 & 68 & $65 a$ & 608 & $\mathrm{TK} 3$ \\
\hline 44 & 132 & 40 & 1.22 & .25 & 1.08 & $.4 \mid$ & 1.11 & .61 & 10 & .70 & $.70 \mid$ & 65.0 & 58.4 & TPACK10 \\
\hline 40 & 142 & 40 & .56 & .26 & 1.11 & .51 & 11.08 & $.4 T$ & IP & .75 & .691 & 67.5 & 60.8 & TPACK6 \\
\hline 5 & 149 & 40 & .07 & .27 & .95 & -.1 & 1.11 & .51 & Q $Q$ & .68 & $.68 \mid$ & 62.5 & 60.9 & TK5 \\
\hline 13 & 143 & 40 & .49 & .26 & 1.09 & $.5 \mid$ & 11.09 & .51 & IR & .50 & $.69 \mid$ & 60.0 & 60.8 & PK2 \\
\hline 42 & 133 & 40 & 1.15 & 25 & 11.09 & أ. & 1.07 & 4 i & is & .68 & 69 & 60.0 & 58.8 & TPACK 8 \\
\hline 22 & 177 & 40 & -2.19 & $.31 \mid$ & 1.07 & $.4 \mid$ & .94 & $.0 \mid$ & |T & .56 & $.59 \mid$ & 62.5 & $68.7 \mid$ & PK11 \\
\hline 15 & 139 & 40 & .76 & .261 & .97 & -11 & 11.06 & .31 & I0 & .54 & .691 & 67.5 & 60.6 & PK4 \\
\hline 23 & 152 & 40 & -.15 & .27 & 1.04 & .21 & | .98 & .01 & iv & .65 & $.67 \mid$ & 60.0 & 60.61 & PCK1 \\
\hline 20 & 163 & 40 & -.98 & .28 & 1.02 & .21 & .96 & $-.1 \mid$ & $\omega$ & .71 & $.65 \mid$ & 57.5 & 61.2 & PK9 \\
\hline 19 & 172 & 40 & -1.72 & .301 & 11.02 & .21 & .89 & -.21 & $x$ & .61 & .621 & 67.5 & 65.1 & PK8. \\
\hline 33 & 150 & 40 & .00 & .27 & .77 & -1.0 & .75 & $-1.1 \mid$ & g & .83 & $.68 \mid$ & 60.0 & $60.7 \mid$ & TPK2 \\
\hline 26 & 168 & 40 & -1.38 & .29 & .74 & -1.2 & .68 & -1.2 & If & .74 & $.63 \mid$ & 75.0 & $63.6 \mid$ & PCK4 \\
\hline 31 & 145 & 40 & .35 & .261 & .70 & -1.4 & .69 & -1.4 & Ie & .82 & .681 & 75.0 & 60.81 & TCK3 \\
\hline 35 & 142 & 40 & .56 & $.26 \mid$ & | .68 & -1.5 & | . .68 & $-1.5 \mid$ & |d & .85 & $.69 \mid$ & 75.0 & 60.81 & TPACK1 \\
\hline y & 155 & 40 & -.31 & .21 & . & $-2.1 \mid$ & | .56 & -2.11 & je & $. \triangleleft<$ & $.6 / 1$ & / & $60 .<1$ & CKS \\
\hline 10 & 147 & 40 & .21 & .27 & .51 & -2.6 & | .54 & $-2.3 \mid$ & b & .77 & $.68 \mid$ & 75.0 & 61.1 & CK4 \\
\hline 16 & 139 & 40 & .76 & $.26 \mid$ & | .53 & -2.4 & .52 & $-2.4 \mid$ & Ia & .72 & $.69 \mid$ & 75.0 & 60.61 & PK5 \\
\hline EAN & 149.5 & 40.0 & .00 & .27 & 1.00 & 이 & 99 & 이 & & & & 65.9 & 61,1 & \\
\hline D. & 10.9 & .0 & .81 & .01 & .25 & 1.1 & | .23 & 1.00 & & & 1 & 5.8 & 1.8 & \\
\hline
\end{tabular}

Gambar 8. Tabel output uji validitas lapangan menggunakan Rasch model instrumen kesiapan guru matemtika pada pembelajaradan daring dalam perspektif TPACK 
DOI: https://doi.org/10.24127/ajpm.v10i3.3980

Berdasar hasil analisis yang dilakukan menggunakan Rasch model (gambar 7), diperoleh nilai logit -2,19 (nilai terendah) untuk pernyataan nomor 22. Ini menunjukkan bahwa pernyataan nomor 22 merupakan pernyataan yang mudah disetujui. Untuk pernyataan nomor 44 diperoleh logit 1,22, ini menunjukkan bahwa pernyataan nomor 44 merupakan pernyataan yang sulit disetujui. Butir pernyataan nomor 1 diperoleh nilai logit Outfit Mean Square (MNSQ) 1,62 > 1,5 yang menunjukkan bahwa pernyataan nomor 1 tidak diterima. Outfit Z-Standard (ZSTD) pada pernyataan nomor 1 adalah 2,3 > 2,0 yang juga menunjukkan bahwa butir nomor 1 tidak diterima. Berdasarkan syarat kelayakan butir soal, pernyataan nomor 1 tidak memenuhi dua dari tiga kriteria untuk memeriksa kesesuaian butir soal yang tidak sesuai (outliers atau misfis), oleh karena itu untuk memeriksa pemenuhan syarat berdsarkan kriteria ketiga tidak dilakukan. Berdasarkan nilai logit Outfit Mean Square (MNSQ) dan Outfit ZStandard (ZSTD) dapat diputuskan bahwa butir pernyataan nomor 1 tidak dapat digunakan karena tidak memenuhi dua dari tiga kriteria yang telah disyaratkan.

Butir pernyataan nomor 35 memenuhi kriteria Outfit MNSQ yang diterima: $0,68<1,5$. Sementara itu nilai Outfit ZSTD yang diterima: $-0,2<$ ZSTD $(-1,5)<2,0$. Namun pada Nilai Point Measure Correlation (PT Mean Corr) tidak memenuhi kriteria yaitu Nilai Point Measure Correlation dengan nilai $0,88>0,85$. Pada butir pernyaaan 35 meskipun tidak memenuhi kriteria Nilai Point Measure Correlation, pernyataan pada butir 35 masih tetap dipertahankan, hal ini dikarenakan telah memenuhi dua kriteria lainnya, yaitu Outfit MNSQ dan Outfit ZSTD. Berdasarkan analisis Rasch Model, pernyataan yang tidak tidak valid adalah pernyataan nomor 1 .

\section{Penentuan reliabilitas (Establishing Reliability).}

Hasil output analisis uji reliabilitas menggunakan Rasch Model dapat dilihat pada Gambar 9.

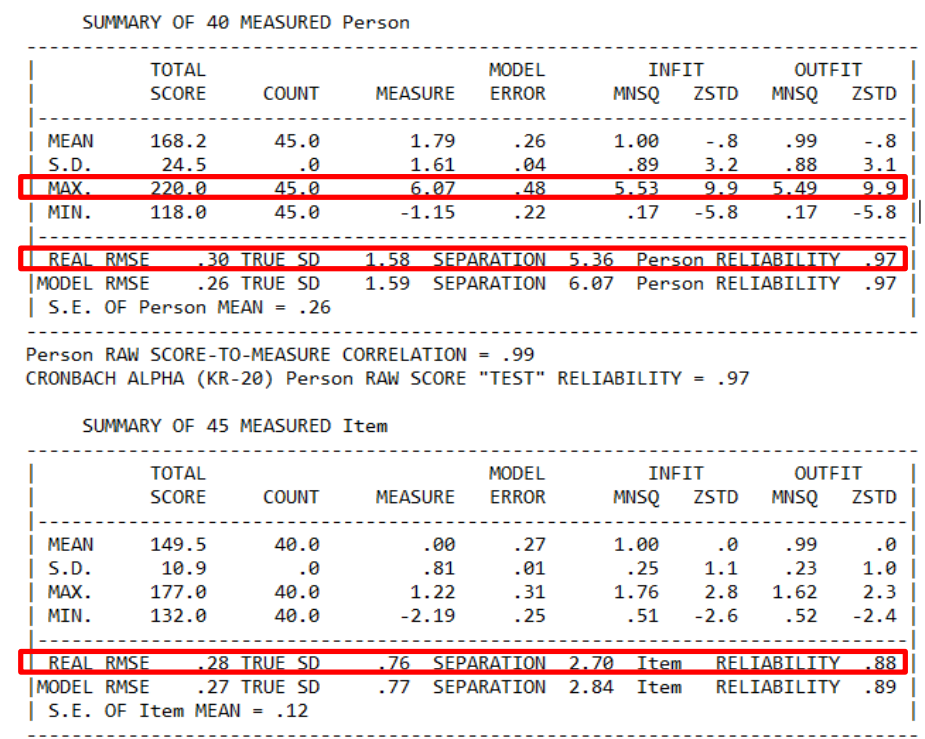

Gambar 9. Tabel output uji reliabilitas menggunakan Rasch model instrumen kesiapan guru matemtika pada pembelajaradan daring dalam perspektif TPACK 
Berdasar analisis yang telah dilakukan, diperoleh nilai Person measure 1,79 yang menunjukkan bahwa penilaian responden bagus (lebih tinggi dari nilai 0,0 logit) kecenderungan abilitas responden lebih besar dari tingkat kesulitan pernyataan. Nilai Alpha Cronbarch 0,97 menunjukkan interaksi antara person dan butir-butir pernyataan secara keseluruhan tergolong bagus sekali. Perseon Reliability 0,97 dan Item Reliability 0,88 menunjukkan bahwa konsistensi jawaban dari responden (guru) tergolong istimewa dan kualitas butir pernyataan pada instrumen reliabilitasnya bagus. Berdasarkan hasil tersebut dapat disimpulkan bahwa instrumen kuisioner untuk mengukur kesiapan guru matematika dalam melakukan pembelajaran daring adalah reliabel.

Berdasarkan uji validitas lapangan dapat diperoleh butir pernyataan yang tidak layak untuk digunakan adalah butir pernyataan 1 . Butir pernyataan tersebut merupakan bagian dari komponen Technology Knowledge (TK) untuk butir pernyataan nomor $1-6$. Sementara itu, untuk butir pernyataan pada komponen Content Knowledge (CK) untuk butir pernyataan nomor 7 11 layak untuk digunakan, Pedagogical Knowledge (PK) untuk butir pernyataan nomor 12 - 22 layak unguk digunakan, Pedagogical Content Knowledge (PCK) untuk butir pernyataan nomor $22-28$ layak unguk digunakan, Technology Content Knowledge (TCK) untuk butir pernyataan nomor 29 - 31 layak untuk digunakan, Technology Pedagogical Knowledge (TPK) untuk butir pernyataan nomor 32 - 34 layak unguk digunakan, dan Technology Pedagogical and Content Knowledge (TPACK) untuk butir pernyataan nomor 35 - 45 layak untuk digunakan.
Beberapa penelitian tentang analisis terhadap kesiapan guru dalam melakukan pembelajaran daring hanya fokus pada kesiapan guru dalam pemanfaatan teknologi dalam pembelajaran seperti e-learning yang digunakan untuk pembelajaran daring (Fajriana \& Safriana, 2021; Jamal S, 2020). Hal ini juga senada dengan penelitian dilakukan oleh Msila; Termit Kaur \& Samili (2015; 2014) yang menyatakan bahwa keberhasilan pembelajaran yang mengintegrasikan teknologi informasi bergantung pada kompetensi guru dan sikap guru terhadap teknologi dan informasi.

Instrumen yang dihasilkan dari penelitian ini tidak hanya mengukur kesipaan guru dalam pemanfaatan teknologi dan informasi dalam pembelajaran khususnya pembelajaran daring, namun juga mengukur kesiapan guru matematika dalam melakukan pembelajaran daring dalam mengintegrasikan aspek pedagogik, penguasaan materi dan penggunaan teknologi. Kemampuan pedagogik, penguasaan materi dan penggunaan teknologi merupakan keterampilan yang tidak dapat dipisahkan satu dengan yang lainnnya pada aktivitas pembelajaran daring. Oleh karena itu dalam mengukur kesiapan guru dalam melakukan pembelajaran daring tidak dapat diukur berdsarkan satu aspek kompetensi/ keterampilan saja. Melalui instrumen yang telah dikembangkan ini akan mampu menjawab lebih spesifik kesiapan guru berdasarkan keterampilan/kompetensi yang dimiliki.

\section{KESIMPULAN DAN SARAN}

Berdasarkan hasil dan pembahasan pada penelitian ini dapat disimpulkan bahwa instrumen kuesioner yang telah dikembangkan secara keseluruhan valid dan reliabel. 
Terdapat ada 1 item pernyataan yang tidak layak digunkaan yaitu pernyataan nomor 1 pada komponen Technological Knowledge (TK) Sementara 44 item pernyataan lainnya tergolong valid dan reliabel. Ini menunjukkan bahwa instrumen kuesioner yang telah dikembangkan layak digunkaan untuk mengukur kesiapan guru matematika dalam melakukan pembelajaran daring perspektif TPACK.

Penelitian pengembangan ini menghasilkan instrumen untuk mengukur kesiapan guru dalam melakukan pembelajaran daring. Secara spesifik dapat mengukur kesipaan guru dalam mengintegrasikan keterampilan/ kompetensi yang dimiliki berupa kemampuan pedagogik, penguasaan materi penggunaan teknologi pada pembelajaran daring. Besar harapan, instrumen ini dapat digunkaan pemangku kepentingan ataupun peneliti lainnya untuk mengukur kesiapan guru matematika dalam melakukan pembelajaran daring perspektif TPACK. Selain itu perlu dikembangkan instrumen kesiapan guru matematika dalam melakukan hybrid/blended learning, untuk mempersiapkan para tenaga pendidik yang mampu beradaptasi dengan era digital.

\section{UCAPAN TERIMA KASIH}

Terima kasih disampaikan pada Pimpinan Universitas Muhammadiyah Palembang yang telah membiayai penelitian ini melalui program Hibah Internal Lembaga Penelitian dan Pengabdian Masyarakat (LPPM) Univesitas Muhammadiyah Palembang.

\section{DAFTAR PUSTAKA}

Azzahra, N. F. (2020). Mengkaji Hambatan Pembelajaran Jarak Jauh di Indonesia di Masa Pandemi Covid-19. Retrieved from https://repository.cips-

indonesia.org/media/309163-

mengkaji-hambatan-pembelajaranjarak-jau-99409337.pdf

Chen, Z., Chen, W., Jia, J., \& An, H. (2020). The effects of using mobile devices on language learning: a meta- analysis. Educational Technology Research and Development, 68(4), 1769-1789. https://doi.org/10.1007/s11423020-09801-5

Fajriana, \& Safriana. (2021). Analisis Kesiapan Guru Fisika dan Matematika dalam Pembelajaran Daring. Jurnal Pendidikan Sains Indonesia, 9(2), 293-304. https://doi.org/10.24815/jpsi.v9i2.1 9162

Jamal S. (2020). Analisis Kesiapan Pembelajaran E-Learning Saat Pandemi Covid-19 Di Smk Negeri 1 Tambelangan. Jurnal Nalar Pendidikan, 8(1), 16-22. https://doi.org/https://doi.org/10.26 858/jnp.v8i1.13561

Kemdikbud. Surat Edaran Menteri Pendidikan dan Kebudayaan Republik Indonesia nomor: , Pub. L. No. 36962/MPK.A/HK/2020 (2020).

Kemdikbud. Surat Keputusan Bersama Menteri Pendidikan dan Kebudayaan Menteri Agama, Menteri Kesehatan, dan Menteri Dalam Negeri RI. , (2020).

Kemp, S. (2020). Digital 2020: Indonesia. Retrieved from Datareportal website: www.datareportal.com

Kiray, S. A. (2016). Development of a TPACK self-efficacy scale for preservice science teachers. International Journal of Research in Education and Science, 2(2), 527-541.

https://doi.org/10.21890/ijres.64750 
Mishra, P., \& Koehler, M. J. (2006). Technological Pedagogical Content Knowledge: A Framework for Teacher Knowledge. Teachers College Record, 108(6), 10171054.

https://doi.org/10.1111/j.14679620.2006.00684.x

Misieng, J.-, Ramanair, J., \& Rethinasamy, S. (2018). Measuring teachers' readiness to use technology. Journal of IT in Asia, $8(1)$, 7-13. https://doi.org/10.33736/jita.852.20 18

Msila, V. (2015). Teacher Readiness and Information and Communications Technology (ICT) Use in Classrooms: A South African Case Study. Creative Education, 06(18), 1973-1981. https://doi.org/10.4236/ce.2015.61 8202

Pratama, L. D., Lestari, W., \& Astutik, I. (2020). Efektifitas Penggunaan Media Edutainment Di Tengah Pandemi Covid-19. AKSIOMA: Jurnal Program Studi Pendidikan Matematika, 9(2), 413-423. https://doi.org/10.24127/ajpm.v9i2. 2783

Samnufida, R., Sugiman, S., \& Retnawati, H. (2021). Teacher's Difficulties Junior High School Communication Mathematics during Online Learning. AKSIOMA: Jurnal Program Studi Pendidikan Matematika, 10(2), 774-785.

https://doi.org/http://dx.doi.org/10. 24127/ajpm.v10i2.3467

Schmidt, D. A., Baran, E., Thompson, A. D., Mishra, P., Koehler, M. J., \& Shin, T. S. (2009). Technological pedagogical content knowledge (Track): The development and validation of an assessment instrument for preservice teachers. Journal of Research on Technology in Education, 42(2), 123-149. https://doi.org/10.1080/15391523.2 009.10782544

Sumintono, B., \& Widhiarso, W. (2013). Aplikasi Model Rasch Untuk Penelitian Ilmu-Ilmu Sosial. Trim Komunikata Publishing House.

Sumintono, B., \& Widhiarso, W. (2015). Aplikasi Pemodelan RASCH pada Assessment Pendidikan. Trim Komunikata Publishing House.

Termit Kaur, R. S., \& Samli, C. (2014). Teacher Readiness on Ict Integration in Teaching-Learning : a Malaysian Case Study. International Journal of Asian Social Science, 4(7), 874-885. Retrieved from http://www.aessweb.com/journals/ 5007\%0ATEACHER

Valtonen, T., Sointu, E., Kukkonen, J., Kontkanen, S., Lambert, M. C., \& Mäkitalo-Siegl, K. (2017). TPACK Updated to Measure Pre-Service Teachers' Twenty-first Century Skills. Australasian Journal of Educational Technology, 33(3), 15-31.

https://doi.org/10.14742/ajet.3518

Yuliani, R. E., \& Heru. (2021). ECourse Design of Middle/MTs Teacher Training Using Google Classroom. International Journal of Elementary Education, 5(3), 350-358. Retrieved from https://ejournal.undiksha.ac.id/inde x.php/IJEE/article/view/37667 